\title{
Peningkatan Prestasi Siswa pada Konsep Fluida Statis dengan Model Pembelajaran Kooperatif Tipe Two Stay-Two Stray (TS-TS) Bervariasi Demonstrasi di Kelas XI IPA SMA Negeri 5 Yogyakarta TA 2012-2013
}

\begin{abstract}
Fadiyah Suryani
SMA Negeri 5 Yogyakarta

J1. Nyi Pembayun 39 Prenggan Kotagede Yogyakarta 55172

Surat-e: fadiyah.suryani@yahoo.com

Tujuan penelitian ini untuk meningkatkan hasil belajar fisika konsep fluida statis pada siswa kelas XI IPA SMA N 5 Yogyakarta tahun ajaran 2012/2013 melalui model Pembelajaran Kooperatif Tipe Two Stay-Two Stray (TS-TS) bervariasi demonstrasi. Penelitian ini dilaksanakan pada kelas XI IPA2 yang berjumlah 36 siswa. Penelitian ini menggunakan penelitian tindakan kelas (action research) sebanyak 2 siklus, dimana setiap siklus meliputi empat tahap yaitu perencanaan, tindakan, pengamatan (obsservasi) dan refleksi. Siklus I Peneliti melakukan demonstrasi pada materi tekanan kemudian siswa berdiskusi sesuai dengan kelompok dan sharing antar kelompok. Dua siswa bertamu(stray) ke kelompok lain dan 2 siswa tetap(stay) berada di kelompok untuk menerima kedatangan dari kelompok lain.Beberapa kelompok mempresentasikan hasil kerja kelompok dan hasil sharing dengan kelompok lain. Dari hasil tes pada siklus I menunjukkan hasil yang belum memuaskan karena ada 15 siswa yang belum tuntas dan kurangnya partisipasi siswa dalam belajar kelompok dan kurang tertib ketika pelaksanaan sharing antar kelompok. Maka diadakan siklus 2 dengan materi hukum Archimedes, teknik pelaksanaan sama seperti siklus I, siswa dapat lebih berpartisipasi aktif dalam kelompok dan pelaksanaan setiap kegiatan pembelajaran berlangsung lebih tertib, siswa tampak termotivasi dalam belaja, hal ini tampak pada saat siswa berdiskusi.. Hasil analisis data menunjukkan bahwa pembelajaran dengan model two stay two stray bervariasi demonstrasi dapat meningkatkan prestasi siswa. Tiap siklus ada peningkatan hasil belajar, yaitu siklus I presentasi ketuntasan $42 \%$, siklus 2 presentase ketuntasan $83 \%$ sehingga ada kenaikan hasil belajar sebesar $41 \%$.
\end{abstract}

Kata kunci: prestasi siswa, konsep fluida pembelajaran two stay two stray, demonstrasi

\section{Pendahuluan}

Mata pelajaran fisika merupakan salah satu mata pelajaran yang tidak disenangi oleh siswa. Ditemukan data bahwa sebagian besar siswa memiliki minat dan kemampuan yang rendah dalam menguasai konsep. Hal ini dapat dilihat dari hasil belajar siswa tahun 201 I/2012 pada konsep fluida memiliki persentase ketuntasan hanya $55 \%$. Berdasarkan pengalaman guru mengajar, ternyata hasil ulangan cenderung memperoleh nilai yang rendah, terbukti pada hasil nilai ulangan harian siswa yang mendapat nilai di bawah Kriteria Ketuntasan Minimal (KKM). Wawancara dengan siswa, ternyata sebagian besar siswa malas belajar dan belum maksimal belajar fisika, karena menganggap fisika identik dengan banyak rumus.

Belajar fisika sebenarnya lebih menekankan penalaran dan pemahaman konsep melalui pembelajaran. Oleh karena itu, belajar fisika dapat membuat siswa kreatif dan dapat memecahkan masalah. Tetapi, tanpa memiliki rasa keingintahuan yang kuat atau motivasi tinggi hal tersebut tidak dapat tercapai.

Dengan adanya variasi metode pembelajaran di kelas diharapkan ada peningkatan kualitas pembelajaran. Siswa semakin termotivasi dalam belajar, daya kreativitas akan semakin meningkat, semakin positif sikap siswa, semakin bertambah jenis pengetahuan dan ketrampilan yang dikuasai. Semakin mantap pemahaman terhadap materi yang dipelajari.

Suherman (2003: 259) mengemukakan bahwa model pembelajaran kooperatif dapat membantu para siswa dalam meningkatkan sikap positif siswa dalam belajar dan dapat mengurangi bahkan menghilangkan rasa cemas yang banyak dialami oleh siswa.

Ada beberapa tipe model pembelajaran kooperatif, salah satunya adalah Two Stay-Two Stray (TS-TS) atau Dua Tinggal-Dua Bertamu. Berbeda dengan tipe yang lain, struktur model pembelajaran kooperatif tipe Two StayTwo Stray memberi kesempatan kepada siswa untuk 
Peningkatan Prestasi Siswa pada Konsep Fluida Statis dengan Model Pembelajaran Kooperatif Tipe Two Stay-Two Stray (TS-TS) Bervariasi Demonstrasi di Kelas XI IPA SMA Negeri 5 Yogyakarta TA 2012-20I3

menyampaikan hasil kerja atau informasi dengan kelompok lain (Lie, 2004: 6I). Diduga, dengan adanya kegiatan berbagi pendapat antarkelompok dapat membiasakan siswa untuk saling menghargai pendapat orang lain dan belajar mengemukakan pendapat kepada orang lain. Hal tersebut terjadi karena tugas kelompok dalam kegiatan berbagi pendapat tidak mungkin dapat diselesaikan tanpa adanya kerja sama yang baik dari setiap anggota kelompok.

Siswa harus dibiasakan untuk berani bertanya dan menyampaikan pendapat, sehingga diharapkan proses pembelajaran fisika lebih bermakna. Oleh karena itu, peneliti tertarik untuk menerapkan model pembelajaran kooperatif tipe $T_{w O}$ Stay-Two Stray sebagai upaya meningkatkan hasil prestasi belajar siswa kelas XI IPA I SMA Negeri 5 Yogyakarta dalam pelajaran fisika dengan menambah variasi dari model ini yaitu demonstrasi sehingga siswa dalam berdiskusi lebih bermakna karena yang di diskusikan sesuatu yang telah mereka lihat dalam kehidupan sehari-hari.

Penelitian ini dilaksanakan untuk tujuan:

I. meningkatkan prestasi hasil belajar fisika siswa kelas XI IPA I SMA Negeri 5 Yogyakarta tahun ajaran 2012/2013 melalui Model Pembelajaran Kooperatif Tipe Two Stay-Two Stray bervariasi demonstrasi;

2. mengetahui respon siswa kelas XI IPA I SMA Negeri 5 Yogyakarta tahun ajaran 201I/2012 terhadap pelaksanaan pembelajaran dengan Model Kooperatif tipe $T_{w o}$ Stay-Two Stray bervariasi demonstrasi.

\section{Kajian Pustaka \\ Prestasi Belajar}

Prestasi belajar siswa adalah gambaran kemampuan siswa yang diperoleh dari hasil penilaian proses belajar siswa dalam mencapai tujuan pengajaran. Prestasi belajar berupa adanya perubahan sikap dan tingkah laku setelah menerima pelajaran atau setelah mempelajari sesuatu.

Prestasi belajar menurut Bloom meliputi 3 aspek yaitu kognitif, psikomotorik dan afektif. Dalam penelitian ini aspek yang ditinjau adalah kognitif yang meliputi pengetahuan, pemahaman dan penerapan.

\section{Pengertian Pembelajaran}

Proses pembelajaran berbeda dengan proses belajar. Proses belajar bersifat internal dan unik dalam diri individu siswa, sedangkan pembelajaran bersifat eksternal yang sengaja direncanakan dan bersifat rekayasa perilaku. Pembelajaran pada hakikatnya untuk mengembangkan aktivitas dan kreativitas peserta didik melalui berbagai interaksi dan pengalaman belajar.

\section{Model pembelajaran kooperatif tipe Two Stay-Two Stray}

Two Stay-Two Stray (TS-TS) merupakan salah satu tipe model pembelajaran kooperatif yang dikembangkan oleh Kagan (1992). Model pembelajaran ini merupakan pembelajaran kooperatif dengan kelompok berempat, yaitu kelompok yang terdiri dari empat siswa. Beberapa kelebihan kelompok berempat (Lie, 2004: 47) antara lain siswa mudah dipecah menjadi berpasangan, lebih banyak ide yang muncul dan tugas yang bisa diselesaikan daripada kelompok berpasangan atau bertiga.

Model Kooperatif tipe Two Stay-Two Stray terdiri dari tiga tahap utama, yaitu (I) tahap kerja kelompok, (2) tahap berbagi pendapat antarkelompok, dan (3) tahap pelaporan kelompok. Dalam kelas kooperatif, para siswa diharapkan dapat saling membantu, saling mendiskusikan dan berargumentasi untuk mengasah pengetahuan yang mereka kuasai saat itu dan menutup kesenjangan dalam pemahaman masing-masing (Slavin, 2009 : 4).

\section{Demonstrasi}

Tujuan penggunaan metode demonstrasi yaitu: mengajarkan suatu proses atau prosedur yang harus dimiliki siswa, mengonkretkan informasi atau penjelasan kepada siswa dan mengembangkan kemampuan pengamatan pandangan dan penglihatan para peserta didik secara bersama-sama.

\section{Konsep Fluida}

Konsep fluida merupakan salah satu konsep yang terintegrasi dalam mekanika, diajarkan pada siswa SMA kelas XI IPA semester II. Fluida adalah zat yang dapat mengalir dan memberikan sedikit hambatan terhadap perubahan bentuk ketika ditekan. Yang termasuk fluida adalah zat cair dan gas. Fluida dapat dibagi menjadi dua yaitu fluida statis (hidrostatis) mempelajari tentang fluida tak bergerak (diam) dan fluida dinamis (hidrodinamis) mempelajari tentang fluida bergerak/mengalir (Kanginan, 2004 : I49). Penerapan fluida statis dalam percobaan fisika sehari-hari adalah penerapan hukum Pascal, hukum Archimedes, dan persamaan hidrostatis.

\section{Metode Penelitian}

\section{Jenis Penelitian}

Penelitian ini menggunakan rancangan penelitian tindakan yang terfokus dalam kegiatan di kelas sehingga penelitiannya berupa Penelitian Tindakan Kelas. 


\section{Desain Penelitian}

Dalam penelitian ini, peneliti menggunakan Penelitian Tindakan Kelas (PTK) model spiral yang dikembangkan oleh Kemmis dan Taggart (1988) (Robin McTaggart, 1993: 3I). Menurut model spiral dari Kemmis dan Taggart, penelitian tindakan kelas dilaksanakan dalam 4 tahap setiap siklus, yaitu tahap perencanaan (plan), tahap tindakan (act), tahap pengamatan (observe), dan tahap refleksi (reflect).

Tahap perencanaan. Pada tahap ini dilakukan penyusunan Rencana Pelaksanaan Pembelajaran (RPP), Lembar Diskusi Siswa (LDS), kartu berbagi pendapat antarkelompok, lembar observasi pelaksanaan pembelajaran, angket motivasi belajar Fisika siswa, angket respon siswa terhadap pelaksanaan pembelajaran dengan model kooperatif tipe $T_{w o}$ Stay-Two Stray bervariasi demonstrasi, soal tes, pembentukan kelompok belajar siswa, dan menyiapkan alat peraga yang dibutuhkan dalam demonstrasi.

Tahap tindakan. Pada tahap ini dilakukan tindakan yaitu penerapan model pembelajaran kooperatif tipe $T_{w O}$ Stay-Two Stray bervariasi demonstrasi. Adapun secara garis besar, tahap-tahap pelaksanaan model pembelajaran kooperatif tipe $T_{w o}$ Stay-Two Stray bervariasi demonstrasi, yaitu demonstrasi alat, tahap kerja kelompok, berbagi pendapat antar kelompok, dan pelaporan kelompok.

Tahap observasi. Pada tahap ini dilakukan pengamatan terhadap proses pembelajran yang ada di kelas semala embelajaran berlangsung. Seluruh pengamatan dicatat dalam berkas-berkas yang sudah disiapkan.

Tahap refleksi. Setelah pembelajaran selesai, segera dilakukan refleksi terhadap hasil pengamatan. Pada tahap ini dilakukanperenungan terhadap seluruh rangkaian dalam satu siklus sebagai bahan untuk menuju siklus berikutnya.

\section{Instrumen Penelitian}

Instrumen yang digunakan dalam penelitian ini yaitu (I) lembar obesrvasi pelaksanaan pembelajaran, (2) angket respon siswa, (3) soal tes akhir siklus, (4) dokumen pembelajaran.

\section{Teknik Analisis Data}

Teknik yang digunakan dalam penelitian ini adalah reduksi data, deskriptif, kuantitatif dan triangulasi data.

\section{Pembahasan}

\section{Hasil Penelitian Tindakan Kelas}

Peningkatan Prestasi Siswa pada Konsep Fluida Statis dengan Model Pembelajaran Kooperatif Tipe Two Stay-Two Stray (TS-TS) Bervariasi Demonstrasi di Kelas XI IPA SMA Negeri 5 Yogyakarta TA 2012-20I3

Berdasarkan hasil angket respon siswa terhadap pelaksanaan pembelajaran model kooperatif tipe $T_{w O}$ Stay-Two Stray, dapat dilihat persentase skor tiap indikator pada tabel I.

Tabel I. Hasil Angket Respon Siswa terhadap Pelaksanaan Pembelajaran dengan Model Pembelajaran Kooperatif Tipe Two Stay-Two Stray

\begin{tabular}{clcc}
\hline No. & Aspek & Persentase & Kualifikasi \\
\hline I & Belajar kelompok & $82 \%$ & Tinggi \\
$\cdot 2$ & Kerja sama dalam kelompok & $87 \%$ & Tinggi \\
$\cdot$ & Sharing pendapat antar-kelompok & $85 \%$ & Tinggi \\
\hline & & & Tinggi \\
\hline & Keseluruhan proses pembelajaran & $82 \%$ & \\
\hline \multicolumn{2}{l}{ Rata-Rata } & $84 \%$ & Tinggi \\
\hline
\end{tabular}

Sedangkan untuk hasil tes siklus I dan 2 dapat dapat disajikan dalam bentuk grafik seperti Gambar I.

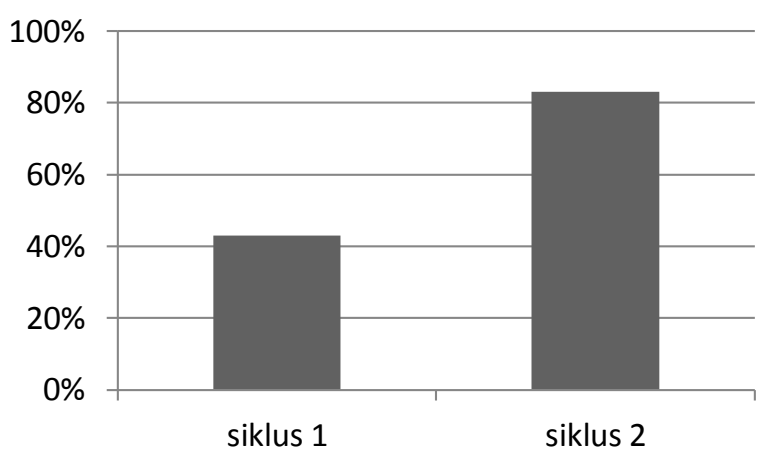

Gambar I. Grafik hasil tes siklus I dan siklus 2

\section{Hasil Observasi Pelaksanaan Pembelajaran dengan Model Kooperatif tipe Two Stay-Two Stray}

Penelitian tindakan kelas ini dilaksanakan dalam dua siklus dengan empat kali pertemuan (6 jam pelajaran), yaitu siklus I dilaksanakan dalam dua kali pertemuan (3 jam pelajaran) dan siklus II dilaksanakan dalam dua kali pertemuan (3 jam pelajaran). Pada setiap siklus, guru sudah berusaha menerapkan model pembelajaran kooperatif Tipe $T_{w o}$ Stay-Two Stray bervariasi demonstrasi dengan baik. Secara umum, pelaksanaan pembelajaran berlangsung dengan lancar walaupun terdapat beberapa kendala yang menjadi keterbatasan peneliti. Pada pertemuan I siklus I, siswa masih merasa bingung dalam melaksanakan pembelajaran dengan kerja kelompok, berbagi pendapat antarkelompok, pelaporan kelompok.

Kerja kelompok. Secara umum, kerja sama kelompok belajar siswa pada setiap siklus berlangsung dengan baik. Para siswa dapat saling membantu dan bekerja sama 
Peningkatan Prestasi Siswa pada Konsep Fluida Statis dengan Model Pembelajaran Kooperatif Tipe Two Stay-Two Stray (TS-TS) Bervariasi Demonstrasi di Kelas XI IPA SMA Negeri 5 Yogyakarta TA 2012-20I3

dengan baik dalam kelompok. Para siswa juga ulet dalam menyelesaikan tugas-tugas yang diberikan, yaitu dengan bertanya kepada guru atau teman bila mengalami kesulitan, berdiskusi dengan serius, mencari informasi tambahan dari buku-buku fisika, bahkan ada beberapa kelompok yang berinisiatif untuk melakukan peragaan untuk mendapatkan gambaran mengenai kasus yang dihadapi.

Pada siklus I pertemuan I, diskusi siswa dalam kelompok berlangsung cukup baik. Namun, rata-rata hanya satu atau dua siswa yang aktif berpendapat dalam kelompok, sisanya masih pasif dalam menyampaikan pendapatnya. Diskusi kelompok pada pertemuan II berlangsung lebih baik daripada pertemuan sebelumnya. Keterlibatan siswa semakin terlihat pada siklus II. Para siswa terlihat antusias dalam berdiskusi kelompok untuk menyelesaikan tugas yang diberikan. Bahkan ada beberapa kelompok yang berinisiatif untuk bekerja sama melakukan peragaan untuk mendapatkan gambaran mengenai kasus yang dihadapi.

Berbagi pendapat antar-kelompok. Berbagi pendapat antarkelompok pada setiap siklus berlangsung dengan baik. Para siswa dapat menjalankan perannya masingmasing dengan baik. Masalah yang peneliti temukan dalam proses berbgai pendapat pada siklus I pertemuan I adalah ada beberapa "siswa tamu" kurang tertib dalam berkunjung (tidak mematuhi rute kunjungan). Hal tersebut berdampak ada kelompok yang mengalami kekosongan (kekurangan "siswa tamu”).

Pada siklus I pertemuan II, "siswa tamu" dapat mematuhi rute kunjungan yang telah ditentukan. Namun, pada awal proses sharing pendapat ini ada "siswa tamu" yang terlambat berkunjung karena lalai belum selesai menuliskan jawaban kelompok pada kartu sehingga siswa terlihat berjejal pada satu tempat karena "siswa tamu" dari kelompok lain telah datang. Hal tersebut menyebabkan proses kunjungan menjadi kurang tertib. Proses berbagi pendapat pada siklus II berlangsung dengan lebih tertib daripada sebelumnya.

Pelaporan kelompok. Tahap pelaporan kelompok pada setiap pertemuan berlangsung dengan baik. Para siswa dapat berdiskusi dan menyelesaikan tugasnya dengan baik.

Berdasarkan hasil tes yang dilaksanakan pada akhir siklus I dan II, dapat dilihat persentase ketuntasan hasil belajar siswa, pada siklus I terdapat $42 \%$ siswa yang tuntas dan pada siklus II 83\% siswa yang tuntas.

\section{Pembahasan}

Selama pelaksanaan tindakan pada setiap siklus, peneliti sudah menerapkan model pembelajaran kooperatif Tipe Two Stay-Two Stray bervariasi demonstrasi dengan baik. Secara umum, pelaksanaan pembelajaran berlangsung dengan lancar walaupun terdapat beberapa kendala yang menjadi keterbatasan peneliti. Pelaksanaan pembelajaran dengan model pembelajaran kooperatif tipe Two StayTwo Stray bervariasi demonstrasi pada siklus I mengalami beberapa kendala, yaitu kurangnya partisipasi siswa dalam belajar kelompok dan kurang tertibnya pelaksanaan berbagi pendapat antar-kelompok. Hal tersebut terjadi karena masih barunya model pembelajaran kooperatif tipe Two Stay-Two Stray bervariasi demonstrasi bagi siswa.

Pada tahap kerja kelompok, pada umumnya kerja sama kelompok belajar siswa pada setiap siklus berlangsung dengan baik. Para siswa dapat saling membantu dan bekerja sama dengan baik dalam kelompok. Para siswa juga ulet dalam menyelesaikan tugas-tugas yang diberikan, yaitu dengan bertanya kepada guru atau teman bila mengalami kesulitan, berdiskusi dengan serius, mencari informasi tambahan dari buku-buku fisika, bahkan ada beberapa kelompok yang berinisiatif untuk melakukan peragaan untuk mendapatkan gambaran mengenai kasus yang dihadapi. Diskusi kelompok pada siklus I berlangsung cukup baik. Beberapa siswa yang pada pertemuan I cenderung pasif mulai menjadi aktif dalam berdiskusi pada pertemuan-pertemuan berikutnya. Keterlibatan siswa semakin terlihat pada siklus II. Para siswa dapat menjalankan perannya masing-masing dengan baik. Masalah yang peneliti temukan dalam proses berbagi pendapat pada siklus I adalah kurang disiplinnya siswa dalam berkunjung sehingga proses berbagi pendapat berlangsung kurang tertib. Namun demikian, proses berbagi pendapat pada siklus II dapat berlangsung lebih tertib daripada sebelumnya, walaupun masih ada kelompok yang berlebih "siswa tamu" akibat perbedaan kecepatan dalam berbagi yang tidak dapat dihindari. Tahap selanjutnya yaitu tahap pelaporan kelompok berlangsung dengan baik pada setiap siklus dan tidak mengalami kendala apapun. Para siswa dapat berdiskusi dan menyelesaikan tugasnya dengan baik.

Pelaksanaan pembelajaran fisika dengan model kooperatif tipe Two Stay-Two Stray bervariasi demostrasi direspon positif oleh siswa. Berdasarkan hasil angket respon siswa terhadap pelaksanaan pembelajaran dengan model kooperatif tipe $T_{W O}$ Stay-Two Stray, diketahui rata-rata persentase skor dari aspek-aspek pembelajaran berada dalam kategori tinggi, yaitu sebesar 84\%.

Adapun ketuntasan hasil belajar siswa ditentukan oleh Kriteria Ketuntasan Minimal SMA Negeri 5 Yogyakarta yaitu sebesar 75. Berdasarkan hasil tes akhir siklus, diketahui bahwa banyaknya siswa yang tuntas dalam belajar fisika mengalami peningkatan yang cukup besar pada siklus II dibanding siklus I, yaitu dari $42 \%$ pada siklus I menjadi $83 \%$ pada siklus II dari 36 siswa yang ada di kelas XI IPA 2 SMA Negeri 5 Yogyakarta tahun ajaran 2012/2013.

Selain itu, adanya respon positif siswa terhadap pelaksanaan pembelajaran dengan model kooperatif tipe Two Stay-Two Stray bervariasi demonstrasi dan 
Peningkatan Prestasi Siswa pada Konsep Fluida Statis dengan Model

Pembelajaran Kooperatif Tipe Two Stay-Two Stray (TS-TS) Bervariasi

Demonstrasi di Kelas XI IPA SMA Negeri 5 Yogyakarta TA 2012-20I3

peningkatan persentase ketuntasan hasil belajar siswa mengindikasikan bahwa model pembelajaran kooperatif tipe Two Stay-Two Stray juga telah mendukung proses belajar fisika siswa kelas XI IPA 2 SMA Negeri 5 Yogyakarta. Terdapat dua macam faktor yang mempengaruhi proses dan hasil belajar siswa, yaitu faktor dalam (internal) dan faktor luar (eksternal). Dalam hal ini model pembelajaran kooperatif tipe $T_{\text {wo }}$ Stay-Two Stray berperan sebagai faktor eksternal, sedangkan motivasi belajar merupakan faktor internal.

Meningkatnya persentase ketuntasan hasil belajar siswa kelas XI IPA I SMA Negeri 5 Yogyakarta, dari siklus I ke siklus II merupakan indikator keberhasilan dalam penelitian ini. Hasil penelitian yang telah diperoleh menunjukkan bahwa indikator keberhasilan tersebut telah terpenuhi sehingga siklus III tidak diperlukan.

\section{Kesimpulan}

Berdasarkan hasil penelitian dan pembahasan, dapat disimpulkan hal-hal sebagai berikut :

I. Model pembelajaran kooperatif tipe $T_{w o}$ Stay-Two Stray bervariasi demonstrasi dapat meningkatkan prestasi belajar siswa. Ini dibuktikan pada siklus I presentase ketuntasan $42 \%$ sedangkan pada siklus 2 presentase ketuntasan $83 \%$.

2. Berdasarkan hasil angket respon siswa terhadap model pembelajaran kooperatif tipe Two Stay-Two Stray bervariasi demonstrasi diperoleh hasil dengan kualifikasi tinggi dengan presentase $84 \%$, sehingga pembelajaran ini dapat diterima dengan baik oleh siswa.

\section{Kepustakaan}

Suherman Erman. 2003. Common Text Book (Edisi Revisi), Strategi Pembelajaran Matematika Kontemporer. Bandung: JICA

Lie Anita. 2004. Cooperative Learning, Mempraktikkan Cooperative Learning di Ruang-Ruang Kelas. Jakarta: PT Grasindo

Slavin Robert E. 2009. Cooperative Learning Teori Riset dan Praktik. Bandung : Nusa Media

Kanginan Marthen. 2004. Fisika 2B untuk SMA kela XI. Jakarta: Erlangga

Mc. Taggart, Robin, I99I, "Action Reserch: A Short Modern History, Victoria:Deakin University Press 